Dicle Tıp Dergisi / Dicle Med J (2019) 46 (3) : 489 - 498

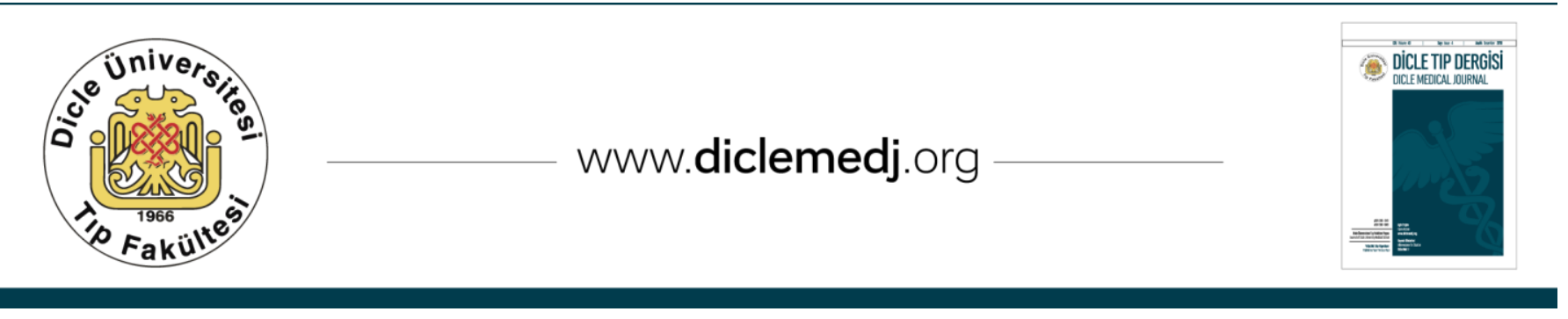

Original Article / Özgün Araştırma

\title{
The use of empirical antibiotics in intensive care unit and relationship between nutrition and the incidence of infection
}

\author{
Salih Yıldırım¹, Yavuz Orak2 , Rukiye Menemencioğlu ${ }^{3}$, Ahmet Altun ${ }^{4}$, Filiz Orak ${ }^{5}$, \\ Cevdet Düger6, Esra Özpay ${ }^{7}$, Fatih Mehmet Yazar ${ }^{8}$ \\ 1Anesthesiology and Reanimation Department, Numune Hospital, Sivas, Turkey ORCID: 0000-0002-4986-6812 \\ 2 Anesthesiology and Reanimation Department. Sutcu Imam University Faculty of Medicine, Kahramanmaraș, Turkey ORCID:0000-0002-8356-6223 \\ 3 Pharmacy Department, Numune Hospital, Sivas, Turkey ORCID:0000-0002-7053-8143 \\ 4 Pharmacology Department, Cumhuriyet University Faculty of Medicine, Sivas, Turkey ORCID:0000-0003-2056-8683 \\ 5 Microbiology Department, Sutcu Imam University Faculty of Medicine Kahramanmaraș, Turkey ORCID:0000-0001-5153-7391 \\ 6 Anesthesiology and Reanimation Department, Cumhuriyet University Faculty of Medicine, Sivas, Turkey ORCID:0000-0002-3845-8733 \\ 7 Department of Nutrition. Numune Hospital, Sivas, Turkey ORCID:0000-0003-0187-9910 \\ 8 General Surgery Department, Sutcu Imam University Faculty of Medicine. Kahramanmaraș, Turkey ORCID:0000-0002-1780-6962
}

Received: 11.04.2019; Revised: 21.06.2019; Accepted: 11.07.2019

\begin{abstract}
Objective: Aim of study is to determine which antibiotic is started empirically in the ICU and to investigate whether the antibiotic started according to culture result was changed or not and the effect of this change on mortality, and to investigate the relationship between mortality and infection by determining whether enteral and parenterally fed patients have attained sufficient calorie level.

Method: After the approval of the local ethics committee, the files of 476 patients hospitalized in our hospital were retrospectively reviewed. A total of 159 patients over 18 years of age who received mechanical ventilation therapy for at least 3 days were included in the study. Blood, urine and tracheal aspirate culture were determined. It was recorded whether antibiotics had changed according to the culture result. Nutritional patterns, number of feeding days and basal caloric need were determined. It was investigated whether basal calorie need was met on 1, 3 and 5 days. Factors affecting mortality were investigated.

Results: Antibiotic exchange was significantly higher in the patients who died $(P=0.002)$. Mortality was higher in patients who were unable to reach the target calorie $(\mathrm{P}=0.01)$. Empirical changes in antibiotics $(\mathrm{r}$ : $0.174, \mathrm{P}=0.028)$, and culture positivity ( $\mathrm{r}: 0.177, \mathrm{P}=0.026$ ) were associated with mortality $(\mathrm{r}: 0.195, \mathrm{P}=0.014)$. In the subgroup analysis, reproduction in tracheal aspirate culture was an important factor affecting mortality (r: 0.211 P: 0.008).

Conclusions: The number of days of hospitalization, antibiotic change, culture positivity and inability to reach the target calories in nutrition are associated with mortality in the intensive care unit.
\end{abstract}

Keywords: empirical antibiotic therapy, mortality, intensive care unit, nutrition.

DOI: $10.5798 /$ dicletip.620514

Yazıșma Adresi / Correspondence: Yavuz Orak, Anesthesiology and Reanimation Department, Kahramanmaraş Sutcu İmam University, Faculty of Medicine Kahramanmaraș, Turkey e-mail: dryavuzorak@hotmail.com 


\section{Yoğun Bakım Ünitesinde Ampirik Antibiyotik Kullanımı ve Beslenmenin, Enfeksiyon Görülme Sıklığı ile İlişkisi}

\section{Öz}

Amaç: Bu çalışmanın amacı YBÜ'nde başlanan ampirik antibiyotiğin, kültür sonuçlarıyla ampirik olarak başlanan antibiyotik değişiminin, hastanın beslenme şeklinin ve karşılanan kalori ihtiyacının mortalite ve enfeksiyon gelişimi üzerine etkisini belirlemekti.

Yöntemler: Lokal etik kurul onayı alındıktan sonra hastanemiz YBÜ’nde yatan 476 hastanın dosyaları geriye dönük tarandı. Çalışmaya 18 yaş üstü, en az 3 gün mekanik ventilatör tedavisi almış 159 hasta dahil edildi. Kan, idrar ve trakealaspirat kültüründe üreme olup olmadığı belirlendi. Kültür sonucuna göre antibiyotiklerin değişip değişmediği kayıt altına alındı. Beslenme şekilleri, beslenme gün sayısı ve bazal kalori ihtiyacı belirlendi. Bazal kalori ihtiyacının 1, 3 ve 5. günlerde karşılanıp karşılanmadığı araştırıldı. Mortaliteye etki eden faktörler araștırıldı.

Bulgular: Ölen hastalarda antibiyotik değişimi anlamlı olarak daha fazlaydı $(\mathrm{P}=0.002)$. Hedef kaloriye ulaşılamayan hastalarda mortalite daha yüksekti $(\mathrm{P}=0.01)$. Ampirik antibiyotik değișimi ( $\mathrm{r}: 0.174, \mathrm{P}=0.028)$, kültür pozitifliği ( $\mathrm{r}: 0.177, \mathrm{P}=0.026)$ hedef kaloriye ulaşamama mortalite ile ilişkiliydi(r:0.195, $\mathrm{P}=0.014)$. Subgrup analizde trakealaspirat kültüründe üreme mortaliteyi etkileyen önemli bir faktördü (r: 0.211 P: 0.008).

Sonuç: Yoğun bakım ünitesinde yatış, gün sayısı, antibiyotik değişimi, kültür pozitifliği ve beslenmede hedef kaloriye ulaşamama mortalite ile ilişkilidir.

Anahtar kelimeler: Ampirik antibiyotik tedavisi, mortalite, yoğun bakım ünitesi, beslenme.

\section{INTRODUCTION}

Despite improvements in intensive care units, both physical and technical, mortality rates are still high. There are many factors that affect this situation. These factors include age, presence of additional disease, and the patient's immunologic response are factors that can not be changed. However, early detection of infection, timely and appropriate antibiotic initiation in the presence of infection, accurate calculation and fulfillment of patients' caloric needs are under the control of health workers ${ }^{1-}$ 3. This situation is very important for patients who are hospitalized and treated in intensive care units (ICU). Systemic inflammatory response syndrome (SIRS), which can develop in patients who are followed up especially in the intensive care unit due to surgery and trauma, is confused with infection. Kumar and colleagues reported $7.6 \%$ increase in mortality with a 1-hour delay in sepsis ${ }^{4}$. Antimicrobial management (AS), including evidence-based standardization, training and communication and implementation audits, has become a important role in preventing the rise in antimicrobial resistance ${ }^{5}$.

Nutritional support is one of the routine treatments applied in the intensive care unit (ICU). Patients who are followed up in intensive care unit should begin feeding within 24- 48 hours after hemodynamic stabilization is achieved. Target calorie (TC) intake should be reached within 48- 72 hours. Target Calorie (TC) can be calculated as 25- $30 \mathrm{kcal} / \mathrm{kg} /$ day ${ }^{6}$.

The purpose of this retrospective crosssectional study is to determine which day of antibiotics is empirically initiated in the intensive care unit and to investigate whether the antibiotic started according to culture result was changed or not and the effect of this change on mortality. At the same time, it is aimed to determine whether the enteral nutrition, parenterally nutrition and enteral nutrion+parenterally nutrition fed patients 
have attained sufficient calorie level and to investigate their relationship with infection.

\section{METHOD}

Ethics committee approval was obtained from local ethics committee (2015-07/10, Dated: July 30, 2015).Our study was carried out retrospectively by reviewing the files of 476 patients who were hospitalized between the dates of 01.01.2014 - 31.06.2015 in intensive care unit in our hospital. 159 patient files of 476 patients were included in the study. Endotracheal intubated patients over 18 years of age and 159 patients who were admitted to the mechanical ventilator for at least three days were included in the study. Poisoned patients and patients who died within the first two days or discharged within the first two days from intensive care unit were not included. 159 patient files were examined. Empirical antibiotics used in patients with signs of infection were recorded. Blood culture, urine culture and tracheal aspirate culture was determined and antibiotics changed according to culture results were determined. Patients were divided into 3 groups in terms of nutrition. Enteral fed, parenteral fed and enteral + parenteral fed group. Nutritional patterns, number of days of nutrition and basal calorie needs have been determined.It has been investigated whether basal calorie needs can be met on days 1, 3 and 5. The amount of calories that patients should take daily was determined according to the recommendations of the European Society for Parenteral and Enteral Nutrition (ESPEN).14 kcal / kg / day for patients with body mass index greater than 30 $\mathrm{kg} / \mathrm{m} 2$; and $25 \mathrm{kcal} / \mathrm{kg} /$ day for patients whose body mass index is below $30 \mathrm{~kg} / \mathrm{m} 2$.

\section{Statistical Analysis}

Statistical tests were made using IBM SPSS for Windows, version 22.0 software (IBM statistics for Windows version 22, IBM Corporation, Armonk, New York, USA). Conformity of the data to normal distribution was examined visually with histograms and analytically with the Kolmogorov-Smirnov and Shapiro Wilk tests. Descriptive analysis results of variables with normal distribution were stated as mean \pm standard deviation (SD) values. Variables not with normal distribution were stated as median and quartile intervals. Data were compared according to URS type using the Student's t-test for variables with normal distribution and the Mann Whitney U-test for variables not showing normal distribution. A value of $\mathrm{p}<0.05$ was accepted as statistically significant.

\section{RESULTS}

Of the 159 patients included in the study, 76 were female $(47.8 \%)$ and 83 were male $(52.2 \%)$. The mean age of the patients was $73.14 \pm 12.87$. The demographic and clinical characteristics of the patients are summarized in Table I. 159 patients were grouped as those with and without mortality. The mean age was $69.30 \pm 11.58$ years in the group with mortality (Group 1, $\mathrm{n}=124$ ) and $69.08 \pm 16.18(\mathrm{P}=$ 0.034 ) in the patients with no mortality (Group $2, n=35$ ). Both groups were evaluated for antibiotic change. There was a significant empirical antibiotic change in Group $1(\mathrm{P}=$ 0.002). Blood culture, urine culture and tracheal aspirate cultures were observed in 84 patients. Breeding microorganisms are shown in Figure 1.

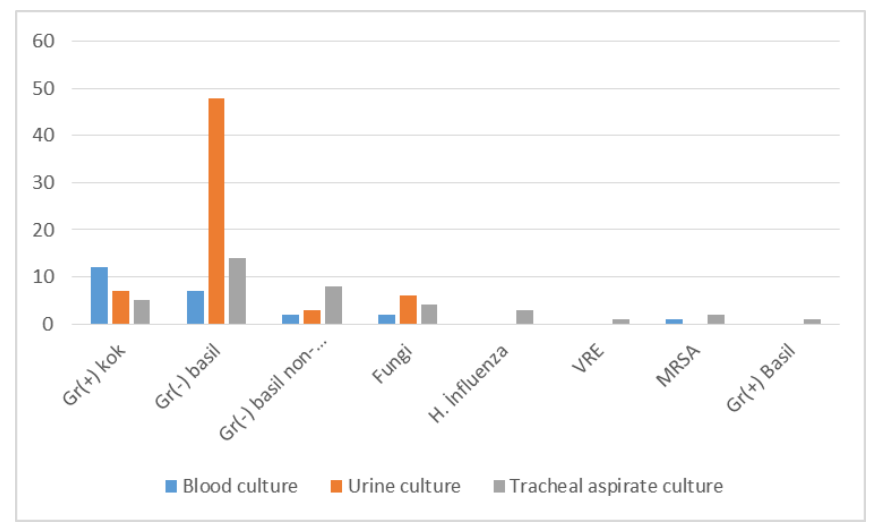

Figure 1: Distribution of micro-organisms produced in cultures 
Table I: Demographic and clinical characteristics of the study participants

\begin{tabular}{|c|c|c|c|}
\hline & & $\begin{array}{l}\text { Number of Patientsor } \\
\text { Average (min-max) }\end{array}$ & $\%$ \\
\hline \multicolumn{2}{|l|}{ Age } & $73.14 \pm 12.87(24-101)$ & - \\
\hline \multicolumn{2}{|l|}{ Gender(K/E) } & $76 / 83$ & $47.8 / 52.2$ \\
\hline \multicolumn{2}{|l|}{ Weight } & $71.84 \pm 12.13(45-120)$ & - \\
\hline \multicolumn{2}{|l|}{ Length of stayingin intensive care } & $17.10 \pm 17.95(2-90)$ & - \\
\hline \multicolumn{2}{|l|}{ APACE II } & $49.19 \pm 17.43$ & - \\
\hline \multicolumn{2}{|l|}{ Basal Requirement } & $1702.19 \pm 252.64(175-2600)$ & - \\
\hline \multirow{7}{*}{ Hospitalization diagnosis } & Trauma & 3 & 1.9 \\
\hline & Cerebro vasculer disease & 51 & 32.1 \\
\hline & Respiratuar disease & 46 & 28.9 \\
\hline & Cardiovasculer disease & 15 & 9.4 \\
\hline & General disesae & 25 & 15.7 \\
\hline & Sepsis & 11 & 6.9 \\
\hline & Others & 8 & 5 \\
\hline \multirow{7}{*}{ Additional Diseases } & No Additional Diseases & 14 & 8.8 \\
\hline & Cardiovasculer disease & 60 & 37.7 \\
\hline & Renal diseases & 15 & 9.4 \\
\hline & Cancer & 7 & 4.4 \\
\hline & DM & 13 & 8.2 \\
\hline & Respiratuar disease & 38 & 18.2 \\
\hline & $\begin{array}{l}\text { Cerebrovasculer disease } \\
\text { Others }\end{array}$ & $\begin{array}{c}14 \\
9\end{array}$ & $\begin{array}{l}7.5 \\
5.8\end{array}$ \\
\hline \multirow{5}{*}{ Antibiotic initiation day } & Empirical Antibiotic No Initiated & 17 & - \\
\hline & Antibiotic started on day 1 & 80 & - \\
\hline & Antibiotic started on day 2 & 15 & - \\
\hline & Antibiotic started on day 3 & 20 & - \\
\hline & Antibiotic started on day 4 andafter & 27 & - \\
\hline \multirow{4}{*}{$\begin{array}{l}\text { Classification according to antimicrobial } \\
\text { initiation days and effect mechanisms }\end{array}$} & $\begin{array}{l}\text { Antibiotics effective on bacterial } \\
\text { cell wall }\end{array}$ & $108 / 15 / 0$ & - \\
\hline & $\begin{array}{l}\text { Antibiotics effective on bacterial } \\
\text { genetic material. }\end{array}$ & $29 / 11 / 1$ & - \\
\hline & $\begin{array}{l}\text { Antibiotics effective on ribosomal } \\
\text { protein synthesis. }\end{array}$ & $3 / 6 / 0$ & - \\
\hline & $\begin{array}{l}\text { Antibiotics effective on the } \\
\text { cytoplasm membrane. }\end{array}$ & $0 / 1 / 0$ & - \\
\hline \multirow[b]{2}{*}{ Nutrition } & Enteral & 26 & 16.35 \\
\hline & $\begin{array}{l}\text { Parenteral } \\
\text { Enteral+Parenteral }\end{array}$ & $\begin{array}{c}127 \\
6\end{array}$ & $\begin{array}{c}79.87 \\
3.8\end{array}$ \\
\hline \multirow{3}{*}{ Reaching to the target calorie } & on 1 day & 42 & 36.8 \\
\hline & on 3day & 74 & 46.3 \\
\hline & on 5day & 86 & 53.8 \\
\hline \multirow{2}{*}{ Treatment Outcome } & Exitus & 124 & 78 \\
\hline & Discharged & 35 & 22 \\
\hline
\end{tabular}


Table II. Evaluation of different clinical parameters of patients in terms of mortality

\begin{tabular}{|c|c|c|c|c|}
\hline & & Groups & & \\
\hline & & $\begin{array}{c}\text { Nonsurvivors } \\
(n=124)\end{array}$ & $\begin{array}{c}\text { Survivors } \\
(\mathrm{n}=35)\end{array}$ & $\mathbf{P}$ \\
\hline Age & & $74.30 \pm 11.58$ & $69.08 \pm 16.18$ & 0.034 \\
\hline $\begin{array}{l}\text { Length of staying in intensive } \\
\text { care }\end{array}$ & & $18.14 \pm 17.66$ & $13.40 \pm 18.76$ & 0.168 \\
\hline Antibiotic initiation day & & $1.80 \pm 1.30$ & $1.54 \pm 1.26$ & 0.290 \\
\hline Hospitalization diagnosis & $\begin{array}{l}\text { Trauma } \\
\text { Cerebro Vasculer Disease } \\
\text { Respiratuar Disease } \\
\text { Cardio vasculer Disease } \\
\text { General disesae } \\
\text { Sepsis } \\
\text { Others }\end{array}$ & $\begin{array}{c}2 \\
39 \\
37 \\
11 \\
21 \\
8 \\
6\end{array}$ & $\begin{array}{c}1 \\
12 \\
9 \\
4 \\
4 \\
3 \\
2\end{array}$ & 0.798 \\
\hline Empirical Antibiotic & $\begin{array}{l}\text { Empiriacal Antibiotic No } \\
\text { Initiated } \\
\text { Changing } \\
\text { Unchanging }\end{array}$ & $\begin{array}{l}11 \\
71 \\
41\end{array}$ & $\begin{array}{c}5 \\
10 \\
20\end{array}$ & 0.002 \\
\hline Nutrition & $\begin{array}{l}\text { Enteral } \\
\text { Parenteral } \\
\text { Enteral+parenteral }\end{array}$ & $\begin{array}{c}18 \\
100 \\
6\end{array}$ & $\begin{array}{c}8 \\
27 \\
0\end{array}$ & 0.235 \\
\hline
\end{tabular}

The patients were divided into two groups according to the result of the treatment. Patients with death were found to have significantly altered antibiotics $(P=0.002)$. Antibiotic changes were investigated according to the reproductive outcome in culture. As a result of culture, it was observed that empirical antibiotic change was made statistically significant in the patients with reproduction $(\mathrm{P}=0.000)$ (Tablo III). When the patients were evaluated in terms of nutritional and nutritional target calorie, it was observed that mortality development was statistically significantly higher in patients who were unable to reach target calorie diet $(\mathrm{P}=0.01)$ (Table III). Factors related to mortality were studied. Empirical antibiotic exchange (r:0.174, $\mathrm{P}=0.028$ ), culture reproduction ( $\mathrm{r}: 0.177$, $\mathrm{P}=0.026)$ and inability to reach the target Calorie (r:0.195, $\mathrm{P}=0.014)$ were associated with mortality. In the subgroup analysis, it was seen that the tracheal aspirate culture result had an effect on mortality (r: 0.211 P: 0.008). Other factors related to mortality are shown in Table IV. Factors affecting mortality were examined in a model generated by multiple logistic regression analysis. Statistically significant results of the model are presented in Table V.

\section{DISCUSSION}

In our study, the use of empirical antibiotics was investigated in patients who were followed up in intensive care unit. In addition, the relationship between nutrition and infection was evaluated. It was observed that the use of empirical antibiotics was not compatible with the culture result and the mortality rates were significantly increased in patients with antibiotic change. It was investigated nutritional way and at same time whether the patients had reached the target calorie. Nutritional patterns of patients were grouped as enteral nutrition, parenteral nutrition, enteral nutrition + parenteral nutrition. 
Table III. Empirical antibiotic change, Reaching to the target calorie, Nutrition Shape, and the relationship between them

\begin{tabular}{|c|c|c|c|c|c|c|c|c|c|c|c|c|}
\hline & & Empiric & tibio & hange & & Reacl & $\begin{array}{l}\text { to } t \\
\text { alori }\end{array}$ & etarget & & rition & & \\
\hline & & 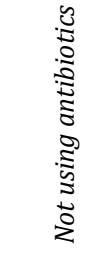 & 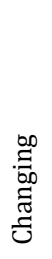 & 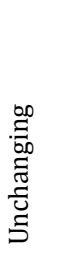 & $a$ & $\stackrel{\infty}{\nu}$ & z & $a$ & 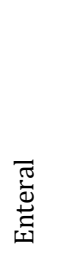 & 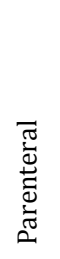 & 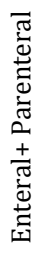 & $a$ \\
\hline & $(+)$ & 0 & 53 & 13 & & 44 & 23 & & 9 & 54 & 4 & 0.351 \\
\hline & $(-)$ & 13 & 36 & 43 & 0.000 & 55 & 37 & 0.270 & 17 & 73 & 2 & \\
\hline & Trauma & 0 & 0 & 3 & & 3 & 0 & & 2 & 1 & 0 & 0.227 \\
\hline & $\begin{array}{l}\text { Cerebro Vasculer } \\
\text { disease }\end{array}$ & 9 & 23 & 19 & & 28 & 23 & & 7 & 40 & 4 & \\
\hline & $\mathrm{RD}$ & 3 & 28 & 14 & & 29 & 17 & & 10 & 36 & 0 & \\
\hline Hospitalizationdi & CVD & 2 & 8 & 5 & & 11 & 4 & & 2 & 13 & 0 & \\
\hline agnosis & General disease & 1 & 13 & 11 & 0.347 & 17 & 8 & 0.346 & 4 & 20 & 1 & \\
\hline & Sepsis & 0 & 5 & 6 & & 8 & 3 & & 1 & 10 & 0 & \\
\hline & other & 1 & 4 & 3 & & 3 & 5 & & 0 & 7 & 1 & \\
\hline & Nonsurvivors & 11 & 71 & 41 & & 71 & 53 & & 18 & 100 & 6 & 0.235 \\
\hline & Survivors & 5 & 10 & 20 & & 28 & 7 & & 8 & 27 & 0 & \\
\hline
\end{tabular}

Data are expressed as the mean \pm SD, unless other wise noted, Independent t test (bootsrap)-Mann-Whitney U test (Monte Carlo)—Fisherexact test (Monte Carlo) CVD: Cardio Vasculer Disease, RD: Respiratuar disease

The mortality rate was significantly higher in the patients who could not achieve the caloric target on the 5th day. In the literature, different results have been reported in studies evaluating the association of inappropriate empirical antibiotic use with mortality in patients followed up in intensive care unit. Corona et al. have shown that empirical antibiotic therapy at 1942 patients with bacteremia has no effect on mortality ${ }^{7}$. In another study appropriate empirical antibiotic treatment indicated no association between mortality and duration of stay in intensive care unit ${ }^{8}$.In a multicenter prospective study conducted by J M Fitzpatrick et al showed that inappropriate use of antibiotics did not correlate with mortality ${ }^{9}$. However, in other studies, it has been reported that mortality increases dramatically in patients in whom empirical antibiotic therapy is not appropriate ${ }^{10-13}$. Luna et al have found culture positivity in bronchoalveolar lavage fluid in 65 of 132 patients who were followed up for ventilator-associated pneumonia. In these patients, mortality was 38\% in patients using appropriate empirical antibiotic therapy, whereas mortality was $91 \%$ in patients receiving inappropriate antibiotics prior to culture from bronchoalveolar lavage fluid ${ }^{14}$. In a study conducted in patients with bacteraemia, hospital mortality was reported to be lower in patients receiving appropriate antimicrobial therapy than in patients in whom antimicrobial therapy was not appropriate $(28.4 \%$ vs. $61.9 \%$ ). In the same study, inappropriate antimicrobial therapy has been shown to be the most important risk factor for hospital mortality ${ }^{11}$.In our study, empirical antibiotic 
therapy was started on days 1, 2 and 3. Within this process, $50.94 \%$ of antibiotics changed. In a prospective study conducted by Dirk Vogelaersa et al in an intensive care unit, the appropriate empirical antibiotic use rate was $63.7 \% 15$. In another study, inappropriate empirical antibiotic use was found to be $34 \%$. In our study, it was observed that mortality rate was increased in patients who had antibiotic change according to culture result. In our study, tracheal aspirate culture was the most effective system for mortality in terms of culture positivity seen in different systems such as blood, urine and tracheal aspirate culture. The results of our study are contradictory to the recent studies in the literature. However, they support the studies made in previous years. The reason for these contradictions in the literature may be due to the methodological differences in the studies and the factors in the diversity of patients and diseases.

Table IV.Evaluation of mortality related factors

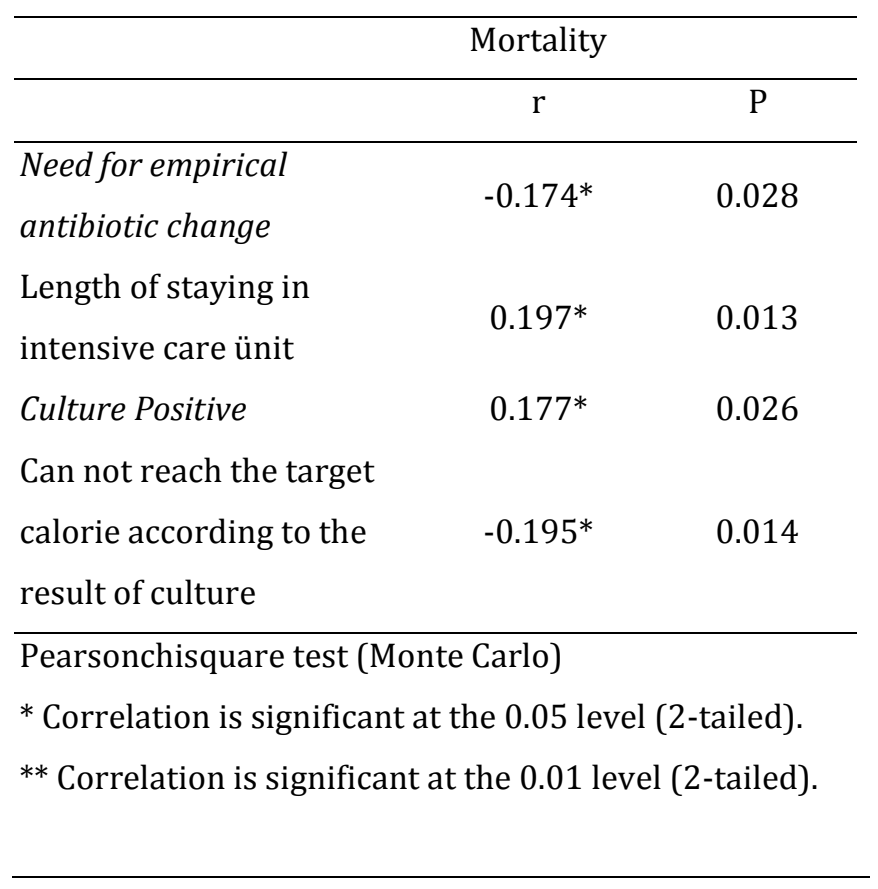

It has been reported that empirical antibiotic therapy for nosocomial infections should be large enough to cover potentially highly resistant bacteria such as P. aeruginosa, EBSL
(Extended Spectrum Beta-Lactamase) producers, Serratia marcescens and Enterobacter cloacae. Therefore, empirical treatment should include cephalosporin, aminoglycoside and / or a glycopeptide ${ }^{16}$. There are studies that emphasize the need to include combinations of monotherapy with a strong ultra-broad spectrum agent (such as carbapenem) ${ }^{17,18}$. When empirically initiated antibiotics were evaluated, antibiotics acting on bacterial wall (cefazolin sodium, ampicillin + sulbactam, piperacillin + tazobactam ...) were used in 123 patients. Antibiotics acting on Bacterial Genetic Material (Florokinolonlar vs ...) were used in 41 patients. Nutrition is one of the essential parts of the management of intensive care patients. It is recommended that patients' caloric needs be met within 24-48 hours. However, observational studies report that $40 \%$ of patients in the intensive care unit do not receive nutritional supplements 19,20 There are studies showing that $60 \%$ of patients who treated more than three days in intensive care units are deprived of nutritional support for 48 hours or more 21 . On the first day of our study, $26.4 \%$ of the patients reached the target calorie level. On the 3rd day, $46.54 \%$ of the patients reached target calorie level. On the 5 th day, $54.08 \%$ the patients reached the target calorie level. It has been reported that the use of nutritional supplements in intensive care units varies between $14 \%$ and $67 \%$. Clinicians prefer parenteral feeding in $12-71 \%$ of patients and prefer enteral feeding in 33-92\% of patients 22,23 . It was observed that the patients we included in our study were fed enteral nutrition $(\mathrm{n}=26)$, parenteral nutrition $(\mathrm{n}=$ 127) or enteral nutrition + parenteral nutrition $(\mathrm{n}=6)$. In the literature, it is suggested to initiate additional parenteral nutrition in intensive care patients who can not reach the target caloric value by enteral route within 7 10 days (24). In the study involving 201 intensive care unit, Heyland et al showed that only $61.2 \%$ of patients were able to reach the target calorie ${ }^{6}$. Similar to this study, $54.08 \%$ of 
the patients reached to the target calorie in our study. The mortality rate in our study was found to be statistically significant in patients who could not achieve the target calorie.

Table V. Factors affecting mortality in backward step wise logistic regression analysis

\begin{tabular}{lccc}
\hline Independentvariables & $\mathrm{B} \pm \mathrm{SE}$ & $\mathrm{p}$ & OR (95\% CI) \\
\hline Empirical antibiotic change & $-4.85 \pm 1.71$ & 0.005 & $0.008(0.000-0.227)$ \\
Antibiotics elected according to culture result & $0.775 \pm 0.310$ & 0.012 & $0.461(0.251-0.845)$ \\
Reaching target calorie & $1.374 \pm 0.497$ & 0.006 & $3.952(1.491-10.479)$ \\
Age & $0.033 \pm 0.015$ & 0.030 & $0.967(0.939-0.997)$ \\
\hline
\end{tabular}

OR oddsratio, CI confidenceinterval

Early enteral nutrition has been associated with reduced morbidity, lower rates of infection, better wound healing, decreased mechanical ventilation time, decreased the length of stay in intencive care unit and hospital $^{25}$, and decreased mortality ${ }^{26}$. In a meta-analysis conducted by Doig et al, It was reported that the standard enteral nutrition at 24th hours of patients admitted to intensive care unit decreased the mortality, pneumonia and infective complications statistically ${ }^{27}$. Recent studies on enteral and parenteral nutrition have produced different results. In a study comparing enteral and parenteral nutrition in patients receiving insufficient oral intake for at least 7 days in 2001, Woodcock et all. concluded that there was no difference in septic morbidity between the two groups ${ }^{28}$. There was no difference in the incidence of sepsis between EN and PN (23.3\% EN vs 31, $7 \% \mathrm{PN}, \mathrm{P}=.438)$ and catheter infection $(6.7 \%$ EN vs. $9.8 \% \mathrm{PN}$ ) in a randomized controlled prospective study by Altintaset all. ${ }^{29}$. In a study conducted in England in 2014, there was no difference in infection complication between PN and EN groups (22\% vs. 21\%) ${ }^{30}$. These results support our work. In our study, patients were grouped as Enteral nutrition, Parenteral Nutrition, Enteral Nutrition + Parenteral Nutrition. It was seen that the mortality rates were significantly higher in patients who could not reach the target calorie. The major limitation of our work is that it is done in one center and the number of patients is relatively small. This reduces the power of the data and makes generalization difficult. Another weakness is the fact that the work is retrospective and there are difficulties in reaching some of the data.

\section{CONCLUSION}

It was observed that the mortality rate was increased in the patients where the empirical antibiotic was changed according to the culture result. In addition, tracheal aspirate culture was the most effective system for mortality in terms of culture positivity seen in different systems such as blood, urine and tracheal aspirate culture. Mortality was found to be significantly higher in the patients who could not achieve the calorie target on the 5th day. Empiric antibiotic therapy and nutritional support are important for patients treated in intensive care unit. It is important to evaluate two different subjects together, which are considered separately in the studies, and we think that this approach also adds value to the study.

Conflicts of interest: The authors have no conflict of interests to declare.

Financial Disclosure: The authors declared that this study has received no financial support. 


\section{REFERENCES}

1. Patel A, Laffan MA, Waheed U, Brett SJ. Randomised trials of human albumin for adults with sepsis: systematic review and meta-analysis with trial sequential analysis of all-cause mortality. BMJ. 2014;349:g4561.

2. Yin M, Si L, Qin W, et all. Predictive Value of Serum Albumin Level for the Prognosis of Severe Sepsis Without Exogenous Human Albumin Administration: A Prospective Cohort Study. J Intensive Care Med. 2018 Dec; 33: 687-94.

3. Kim H, Hur M, Moon HW, Yun YM, Di Somma S. Multimarker approach using procalcitonin, presepsin, galectin-3, and soluble suppression of tumorigenicity 2 for the prediction of mortality in sepsis. Ann Intensive Care. 2017; 7:27.

4. Kumar A, Roberts D, Wood KE et all. Duration of hypotension before initiation of effective antimicrobial therapy is the critical determinant of survival in human septic shock. Crit Care Med 2006; 34: 1589-96.

5. Cooke J, Alexander K, Charani E, et all. Antimicrobial stewardship: an evidence-based, antimicrobial self assessment toolkit (ASAT) for acute hospitals. J Antimicrob Chemother. 2010 Dec; 65: 2669-73.

6. Heyland DK, Dhaliwal R, Drover JW, et all. Canadian Critical Care Clinical Practice Guidelines Committee. Canadian clinical practice guidelines for nutrition support in mechanically ventilated, critically ill adult patients. JPEN J Parenter Enteral Nutr 2003;27: 35573.

7. Corona A, Bertolini G, Lipman J, Wilson AP, Singer M. Antibiotic use and impact on outcome from bacteraemic critical illness: the Bacteraemia Study in Intensive Care (BASIC). J Antimicrob Chemother 2010;65:1276-85.

8. Pouwels KB, Van Kleef E, Vansteelandt S, et all. Does appropriate empiric antibiotic therapy modify intensive care unit-acquired Enterobacteriaceae bacteraemia mortality and discharge? J Hosp Infect. 2017; 96: 23-8.

9. J. M Fitzpatrick, J. S. Biswas, J. D. Edgeworth, et all, on behalf of the United Kingdom Clinical Infection Research Group. Gram-negative bacteraemia; a multicentre prospective evaluation of empiric antibiotic therapy and outcome in English acute hospitals. ClinMicrobiol Infect. 2016; 22:244-51.

10. Harbarth S, Garbino J, Pugin J, et all. Inappropriate initial antimicrobial therapy and its effectonsurvival in a clinical trial of immunomodulating therapy for severe sepsis. Am J Med 2003;115:529-35.

11. Ibrahim EH, Sherman G, Ward S, Fraser VJ, Kollef MH. The influence of inadequate antimicrobial treatment of bloodstream infections on patient outcomes in the ICU setting. Chest 2000;118:146-55.

12. Kollef MH, Sherman G, Ward S, Fraser VJ. Inadequate antimicrobial treatment of infections: a risk factor for hospital mortality among critically ill patients. Chest 1999;115:462-74.

13. Kumar A, Roberts D, Wood KE, et all. Duration of hypotension before initiation of effective antimicrobial therapy is the critical determinant of survival in human septic shock. Crit Care Med 2006;34:1589-96.

14. Luna CM, Niederman MS, Vay C, et all. Impact of BAL data on the therapy and outcome of ventilatorassociated pneumonia. Chest 1997;111: 676- 85.

15. Dirk Vogelaers, David De Bels, Frédéric Forêt, et all. For the ANTHICUS Study Investigators. Patterns of antimicrobial therapy in severe nosocomial infections: empiric choices, proportion of appropriate therapy, and adaptation rates. amulticentre, observational survey in critically ill patients. International Journal of Antimicrobial Agents 2010; 375-81.

16. Colardyn F, Edwards JR. The role of carbapenems in difficultto- treat infections in the ICU. Clin Intensive Care 1996; 7: 19-24.

17. Alvarez-Lerma F, Serious Infection Study Group. Efficacy of meropenem as monotherapy in the treatment of ventilator associated pneumonia. J Chemother 2001;13: 70- 81.

18. Garau J, Blanquer J, Cobo L, et all. Prospective, randomised, multicentre study of meropenem versus imipenem/ cilastatin as empiric monotherapy in severe nosocomial Infections. Eur. J. Clin. Microbiol. Infect. Dis. 1997:16: 789-96.

19. Chakravarty C, Hazarika B, Goswami L, Ramasubban S. Prevalence of malnutrition in a tertiary care hospital in India. Indian J Crit Care Med. 2013;17: 170-3.

20. Mendes R, Policarpo S, Fortuna P, et all. Portuguese NUTRIC Study Group. Nutritional risk assessment and cultural validation of the modified NUTRIC score in critically ill patients - A multicenter prospective cohort study. J Crit Care. 2017;37: 249. 
21. Kalaiselvan MS, Renuka MK, Arunkumar AS. Use of Nutrition Risk in Critically ill (NUTRIC) Score to Assess Nutritional Risk in Mechanically Ventilated Patients: A Prospective Observational Study. Indian Journal of Critical Care Medicine 2017; 21: 253-6.

22. Bhullar HS1, Shaikh FA, Deepak R, Poddutoor PK, Chirla D. Antimicrobial Justification form for Restricting Antibiotic Use in a Pediatric Intensive Care Unit. Indian Pediatr 2016; 53:304-6.

23. Blot S. Limiting the attributable mortality of nosocomial infection and multidrug resistance in intensive care units. Clin Microbiol Infect 2008;14: 513.

24. S.A. McClave, R.G. Martindale, V.W. Vanek, et all. Guidelines for the provision and assessment of nutrition support therapy in the adult critically ill patient. Society of critical care medicine (SCCM) and American society for parenteral andenteral nutrition (A.S.P.E.N), Journal of Parenteral and Enteral Nutrition 2016 Feb; 40: 159-211.
25. Heidegger CP, Darmon P, Pichard C: Enteral vs. parenteral nutrition for the critically ill patient: a combined support should be preferred. Curr Opin Crit Care 2008; 14: 408-14.

26. Gerlach AT, Murphy C.An update on nutrition support in the critically ill. J Pharm Pract 2011; 24: 70-7.

27. Doig GS, Heighes PT, Simpson F, Sweetman EA, Davies AR. Early enteral nutrition, provided within 24 $\mathrm{h}$ of injury or intensive care unit admission, significantly reduces mortality in critically ill patients: a meta-analysis of randomised controlled trials. Intensive Care Med. 2009; 35:2018-27.

28. Woodcock NP, Zeigler D, Palmer MD, Buckley P, Mitchell CJ, Mac Fie J. Enteral versus parenteral nutrition: a pragmatic study. Nutrition. 2001; 17: 112.

29. Altintas ND, Aydin K, Turkoglu MA, Abbasoglu 0, Topeli A. Effect of enteral versus parenteral nutrition on outcome of medical patients requiring mechanical ventilation. Nutr Clin Pract. 2011; 26: 322-9.

30. Harvey SE, Parrott F, Harrison DA, et all. CALORIES Trial Investigators. Trial of the route of early nutritional support in critically ill adults. N Engl J Med. 2014; 371: 1673-84. 